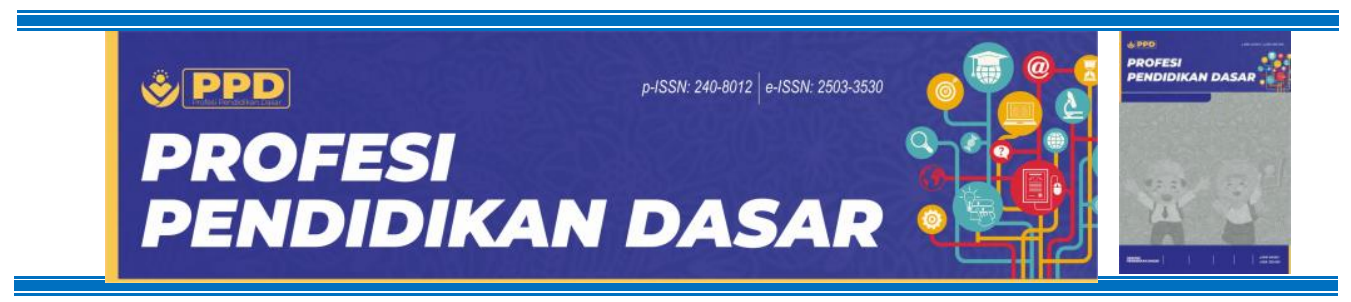

\title{
Efektivitas Pembelajaran Cooperative Script, Artikulasi dan Cooperative Integrated Reading and Composition terhadap Pemahaman Konsep Siswa Sekolah Dasar
}

\author{
Yani Fitriyani $^{{ }^{*}}$, Agus Gunawan ${ }^{2}, \&$ Myrna Apriany Lestari ${ }^{3}$ \\ ${ }^{1}$ Pendidikan Dasar, Universitas Pendidikan Indonesia, Bandung, Indonesia \\ ${ }^{2,3}$ Pendidikan Guru Sekolah Dasar, Universitas Kuningan, Kuningan, Indonesia \\ *Email \& Phone: yanifitriyani@upi.edu +6281222925689 ${ }^{1}$
}

Submitted: $2020-05-27$

DOI: $10.23917 / p p d . v 7 i 2.10971$

Accepted: 2020-12-02

Published: $2020-12-20$

\begin{tabular}{|c|c|}
\hline Keywords: & Abstract \\
\hline $\begin{array}{l}\text { Cooperative } \\
\text { script } \\
\text { Artikulasi } \\
\text { Cooperative } \\
\text { Integrated } \\
\text { Reading and } \\
\text { Composition } \\
\text { Concept } \\
\text { Understanding }\end{array}$ & $\begin{array}{l}\text { This study aims to determine the effectiveness of Cooperative Script (CS), } \\
\text { Artikulasi, and Cooperative Integrated Reading and Composition (CIRC) } \\
\text { learning model on understanding the concepts of elementary school students. } \\
\text { This study used a quasi-experimental research method with Counterbalance } \\
\text { design. This study used sample of 5th grade students in three elementary } \\
\text { schools with total } 75 \text { students. The schools are SDN Pakembangan, SDN } \\
\text { Kutakembaran } 1 \text {, and SDN Kutakembaran 2. The instruments used included a } \\
\text { concept understanding test, observation sheets, and documentation. Data } \\
\text { analysis used was statistical testing with independent t-test which was } \\
\text { previously tested for normality, homogeneity, and two mean difference at a } \\
\text { significant level of } 0.05 \text {. The results showed that the understanding of the } \\
\text { concept of students who took learning with CS was better than students who } \\
\text { took Artikulasi and CIRC. It was reviewed based on the student average score } \\
\text { in the study I was } 75.0 \text {, study II was } 75.2 \text { and } 76.8 \text { in the study III. The results of } \\
\text { the two-difference test mean in study I, II, and III of the CS model obtained a } \\
\text { significant value (2-tailed) } 0.000<0.05 \text {. It means that there is a significant } \\
\text { difference between the use of CS, Artikulasi, and CIRC models. Most of the } \\
\text { students showed a positive attitude towards learning with CS model. Based on } \\
\text { the findings, social studies learning with CS model can be used as an } \\
\text { alternative learning model to improve the concept understanding of } \\
\text { elementary students. }\end{array}$ \\
\hline
\end{tabular}

\section{PENDAHULUAN}

Kualitas kehidupan suatu bangsa tercermin atas mutu pendidikannya. Semakin baik mutu pendidikan, maka kualitas di dalam kehidupan masyarakat pun semakin meningkat (Bintarini et al., 2013). Pendidikan mempunyai peran penting dalam mencerdaskan kehidupan bangsa, atas dasar tersebut setiap orang yang dituntut untuk berperan serta dengan optimal bertujuan memajukan mutu pendidikan (Rosidah, 2016). Dunia pendidikan merupakan sarana untuk melakukan rangkaian kegiatan belajar mengajar melalui pendidikan di sekolah didalamnya terdapat kegiatan belajar mengajar di dalam 
Fitriyani $^{1}$, Gunawan ${ }^{2} \&$ Lestari $^{3}$ - Efektivitas Pembelajaran Cooperative Script ...

kelas. Ilmu pengetahuan sosial (IPS) merupakan integrasi dari berbagai cabang ilmu-ilmu sosial dan humaniora dimana dirumuskan atas dasar realitas dan fenomena sosial yang mewujudkan satu pendekatan interdisipliner dari aspek dan cabang ilmu sosial (Rahmad, 2016). Pembelajaran IPS di sekolah dasar sebagai wahana atau tempat bagi siswa untuk belajar tentang diri sendiri dan lingkungan sekitarnya. Sehingga siswa dapat memilih sikap dan tindakan pada lingkungan sekitar dan sosialnnya. Siswa dapat belajar tentang lingkungan sekitar dan lingkungan sosial melalui pembelajaran IPS di sekolah sehingga dapat mengaplikasikan pada kehidupan sehari-hari.

Peningkatan kemampuan individu melalui pendidikan, seperti pemahaman konsep terhadap suatu materi pembelajaran diharapkan akan mampu meningkatkan kualitas hidup siswa, agar mereka mampu bersaing untuk menghadapi era globalisasi (Fitriyani dan Supriatna, 2019). Pemahaman konsep yang tinggi merupakan salah satu indikator keberhasilan atas tujuan dari proses kegiatan belajar mengajar (Prasetyo, 2014). Semakin tinggi pemahaman konsep yang didapat oleh siswa maka dianggap makin tinggi pula keberhasilan dalam proses pembelajaran di kelas. Pemahaman siswa pada materi pembelajaran terlihat dari siswa yang dapat memahami dan mengetahui tentang suatu hal juga dapat mendeskripsikannya dari berbagai segi. Artinya siswa dapat dikatakan paham tentang sesuatu jika siswa tersebut dapat menjelaskan kembali dengan menggunakan kata-katanya sendiri dan secara detail (Uno dan Umar, 2009).

Hasil observasi dilakukan dalam muatan pembelajaran IPS pada materi pembelajaran tentang masalah sosial menggambarkan hasil yang kurang optimal. Hal ini terlihat dari nilai tes hasil belajar pada materi masalah sosial dari 75 siswa, 32 atau 42,6\% berada di atas nilai KKM dan 43 atau 57,4\% berada dibawah KKM. Selain itu beberapa penemuan di dalam kelas pada muatan IPS di SD belum sesuai dengan tujuan pembelajaran. Telihat guru lebih suka menerapkan teknik pembelajaran yang berpola teoretis dan hafalan hal ini mengakibatkan proses belajar berlangsung kaku, monoton bahkan membosankan (Maftuh, 2013). Demikian rendahnya pemahaman siswa terhadap materi ajar yang diberikan salah satu penyebabnya dalam kesiapan mengajar guru seperti guru belum menerapkan model-model pembelajaran inovatif, cenderung memilah metode yang sudah biasa diterapkan seperti ceramah dan tanya jawab yang akhirnya tidak ada variasi belajar dan mengakibatkan proses belajar terfokus pada satu arah (teacher centered) artinya peran guru dalam melakukan variasi dalam pembelajaran sangat penting (Fitriyani dan Supriatna, 2019). Permasalahan pembelajaran diatas memerlukan pemecahan masalah, dengan penggunaan model pembelajaran yang kompleks sehingga sesuai diharapkan dengan tujuan menumbuhkan minat belajar siswa yang nantinya dapat membuat pemahaman siswa dari materi yang disampaikan oleh guru dapat meningkat (Abidin, 2020). Salah satu model pembelajaran yang dapat diterapkan untuk menyelesaikan permasalahan tersebut dengan menerapkan model Cooperative Learning (Slavin, 2008). Penerapan pembelajaran kooperatif berharap dapat menumbuhkan pemahaman pada bahan ajar dan motivasi belajar siswa yang akhirnya bermuara pada peningkatan prestasi atau hasil belajar peserta didik. Pembelajaran kooperatif merupakan salah satu model pembelajaran guna mendorong siswa untuk dapat berpikir dalam membangun sebuah pemahaman (Gillies, 2003; O'Donnell dan Dansereau, 2000)

Kemudian didukung dengan penemuan Hakim et al., (2019) serta Sundari dan Andriana (2018) yang melaporkan hasil penelitian bahwa model pembelajaran kooperatif mampu meningkatkan pemahaman konsep peserta didik. Model pembelajaran inovatif terleih dahulu dipilih dan disesuaikan bersama bahan dari materi yang akan diajarkan. Model pembelajaran kooperatif tipe Cooperative Script (CS), tipe Artikulasi dan tipe Cooperative Integrated Reading and Composition (CIRC) dapat digunakan dalam pembelajaran IPS. Model pembelajaran CS menurut Maksum dan Sedyawanti (2013); Syafrudin et al., (2019) bahwa model pembelajaran CS merupakan model kooperatif yang dapat membantu guru untuk meningkatkan pemahaman materi pembelajaran yang menghasilkan hasil 
pembelajaran yang meningkat. Berdasarkan hasil penelitian Indriani (2017) mengungkapkan pembelajaran CS memiliki pengaruh, dan dapat meningkatkan pemahaman konsep serta berpengaruh signifikan terhadap penghapusan miskonsepsi siswa dalam pembelajaran PKn pada siswa SD. Selanjutnya hasil penelitian Syafrudin et al., (2019) menjelaskan bahwa pemilihan model CS yang menerapkan model CS dalam pembelajaran telah mampu mengembangkan guru dalam menghasilkan strategi pembelajaran serta dapat meningkatkan keterampilan membaca pemahaman.

Model pembelajaran artikulasi merupakan model pembelajaran yang terdiri atas suatu kelompok kecil yang di dalamnya terdapat dua orang yang berpasangan, dalam model ini seluruh siswa dilibatkan dan mendapatkan peran sehingga siswa memiliki kesempatan untuk menyampaikan pendapat kepada pasangannya, model artikulasi bertujuan untuk melatih kesiapan siswa, membuat interaksi menjadi lebih mudah dan meningkatkan partisipasi anak (Huda, 2019; Suprijono, 2018). Hal tersebut sejalan dengan hasil penelitian yang dilakukan Sundari dan Andriana (2018) yang membuktikan adanya peningkatan pemahaman konsep siswa dalam penerapan model pembelajaran artikulasi terlihat terdapat peningkatan dari tiap siklusnya. Pada siklus I terlihat dari hasil skor rerata yaitu 66,70 dengan presentase $60 \%$. Pada siklus II skor rerata meningkat menjadi 83,60 dengan presentase $84 \%$ hal ini mengindikasikan bahwa model Artikulasi berpengaruh terhadap pemahaman konsep siswa kelas $\mathrm{V}$ sekolah dasar. Model pembelajaran cooperative integrated reading and composition (CIRC) merupakan salah satu model kooperatif yang ekstensif diterapkan dalam pembelajaran membaca, menulis, dan seni berbahasa dilaksanakan dengan cara membentuk kelompok bertujuan agar siswa mampu bekerjasama dengan teman satu kelompoknya untuk menemukan suatu ide pokok suatu materi pembelajaran (Christina \& Kristin, 2016; Rahman, 2019; Suprijono, 2018). Penentuan model pembelajaran CIRC berdasarkan hasil penelitian sebelumnya dengan menerapkan model pembelajaran CIRC terhadap peningkatan membaca pemahaman siswa sekolah dasar. Hasil penelitian yang dilakukan Ariawan et al., (2018) hasil penelitiannya mengindikasikan model CIRC berbantuan media cetak berpengaruh terhadap membaca pemahaman siswa sekolah dasar. Selanjutnya penelitian Marliana et al., (2019) hasil penelitiannya di kelas XI SMA diperoleh bahwa kemampuan membaca akhir siswa menggunakan pembelajaran CIRC lebih tinggi daripada siswa yang tidak menggunakan pembelajaran CIRC.

Selain penelitian di atas, masih terdapat penelitian-penelitian yang dilakukan terkait model pembelajaran cooperative learning di berbagai jenjang pendidikan. Oleh karenanya, peneliti mencoba untuk mengimplementasikan model pembelajaran pada penelitian ini berupa model pembelajaran CS, Artikulasi dan CIRC yang diharapkan dapat meningkatkan pemahaman konsep siswa SD pada mata pelajaran IPS. Penelitian ini dilakukan dengan tujuan melihat efektivitas model CS, Artikulasi dan CIRC terhadap pemahaman konsep siswa pada mata pelajaran IPS. Apakah model ini efektif diterapkan atau tidak terhadap pemahaman konsep siswa pada muatan pembelajaran IPS di sekolah dasar. Sehingga menjadi bahan evaluasi dalam mengembangkan pembelajaran yang inovatif, selain itu penelitian ini juga dapat menjadi bahan kajian terkait pemahaman konsep siswa pada muatan pembelajaran IPS di sekolah dasar.

\section{METODE}

Pendekatan di dalam penelitian ini adalah pendekatan kuantitatif. Adapun metode penelitian yang digunakan adalah metode kuasi eksperimen dengan menggunakan Desain Counterbalanced design. Dalam desain penelitian ini digunakan tiga kelas yang mana ketiga kelas tersebut merupakan kelas eksperimen yang semuanya diberikan treatment yang sama dengan perbedaan pada sub bahasan. Desain penelitian Counterbalanced Design tidak diberikan pretest namun hanya diberi posttest yang digunakan sebagai tolak 
Fitriyani $^{1}$, Gunawan ${ }^{2} \&$ Lestari $^{3}$ - Efektivitas Pembelajaran Cooperative Script ...

ukur untuk melihat ketercapaian dalam pembelajaran dengan tujuan untuk mengetahui efektivitas model pembelajaran CS, Artikulasi dan CIRC terhadap pemahaman konsep siswa kelas V SD. Desain penelitian ini terdapat tiga kelompok eksperimen yang dipilih secara acak, bila dibuat tabel sebagai berikut (lihat Tabel 1):

Tabel 1. Counterbalanced design

\begin{tabular}{ccccccc}
\hline SDN PKB & $\mathrm{X}_{1}$ & $\mathrm{O}_{1}$ & $\mathrm{X}_{2}$ & $\mathrm{O}_{2}$ & $\mathrm{X}_{3}$ & $\mathrm{O}_{3}$ \\
SDN 1 & $\mathrm{X}_{2}$ & $\mathrm{O}_{2}$ & $\mathrm{X}_{3}$ & $\mathrm{O}_{3}$ & $\mathrm{X}_{1}$ & $\mathrm{O}_{1}$ \\
SDN 2 & $\mathrm{X}_{3}$ & $\mathrm{O}_{3}$ & $\mathrm{X}_{1}$ & $\mathrm{O}_{1}$ & $\mathrm{X}_{2}$ & $\mathrm{O}_{2}$ \\
\hline
\end{tabular}

Sumber: (Fraenkel et al., 2012:253)

Keterangan :

$\mathrm{X}_{1} \quad=$ Penerapan Model CS

$\mathrm{X}_{2} \quad=$ Penerapan Model Artikulasi

$\mathrm{X}_{3}=$ Penerapan Model CIRC

$\mathrm{O}_{1,2,3} \quad=$ Posttest pada setiap kelompok

Partisipan penelitian yang terlibat adalah siswa kelas 5 SDN Pakembangan, SDN 1 Kutakembaran, dan SDN 2 Kutakembaran, Kecamatan Garawangi, Kabupaten Kuningan, Jawa Barat. Adapun Instrumen yang digunakan untuk pengumpulan data berupa soal tes pemahaman konsep dan lembar observasi, Uji coba instrumen, diuji validitas dan reliabilitas. Instrumen dikatakan reliabel jika nilai alpha $>0,05$. Uji reliabilitas dilakukan dengan menggunakan SPSS versi 22 melalui langkah Analyze-Scale-Reliability-Analysis. Keberhasilan suatu penelitian dapat diukur melalui ketercapaian indikator yang dijadikan sebagai acuan keberhasilan atau keefektifan penelitian. Implementasi model pembeljaaran CS, artikulasi dan CIRC terhadap pemahaman siswa dikategorikan berhasil apabila $85 \%$ nilai siswa memenuhi KKM yaitu 70. Teknik analisis data dalam penelitian ini meliputi data kuantitatif dilakukan dengan beberapa tahapan, antara lain (1) analisis data deskriptif, (2) analisis uji normalitas dan homogenitas, (3) analisis uji perbedaan dua rerata pada taraf signifikansi 0,05 dengan menggunakan uji $t$ independent dengan berbantuan software SPSS Versi 22. Adapun norma keputusan yang digunakan dalam pengujian hipotesis yaitu, jika t- hitung $\geq \mathrm{t}_{\text {tabel, }}$, dengan alfa 0,05 maka signifikan, artinya Ha diterima, Ho ditolak dan jika $t_{-}{ }_{\text {hitung }}<\mathrm{t}_{\text {tabel, }}$, dengan alfa 0,05 maka tidak signifikan, artinya $\mathrm{Ha}$ ditolak, Ho diterima.

\section{HASIL DAN PEMBAHASAN}

Sebelum melakukan penelitian, peneliti terlebih dahulu melaksanakan observasi dan wawancara bertujuan melihat konteks nyata yang terdapat di sekolah selain itu melakukan pencarian informasi mengenai proses belajar mengajar serta mendapatkan berbagai permasalahan yang dihadapi sekolah dalam proses kegiatan belajar mengajar dalam muatan IPS khususnya di kelas 5. Hasil tes pembelajaran IPS pada materi masalah sosial siswa kelas 5 menunjukan siswa yang mendapat nilai di atas KKM (tuntas belajar) sebanyak 32 siswa (42,6\%), sedangkan siswa yang mendpaat nilai di bawah KKM (tidak tuntas belajar) sebanyak 43 siswa $(57,4 \%)$. Pemahaman konsep materi masalah sosial yang rendah ini perlu diatasi agar meningkat yaitu dengan cara menerapkan model pembelajaran tipe CS, artikulasi dan CIRC. Terlihat dari hasil tes tersebut maka harus dilakukan penelitian dalam penggunaan model pembelajaran yang inovatif guna meningkatkan kemampuan siswa dalam memahami konsep pada materi pembelajaran tentang masalah sosial. 


\section{Skor Rerata Posttest}

Berdasarkan teknik analisis data yang digunakan, perbandingan hasil post test dari berbagai model pembelajaran dan kelas terlihat di setiap pertemuan di mana untuk kejelasan lebih dalam setiap kriteria penilaian disajikan dalam Gambar 1.

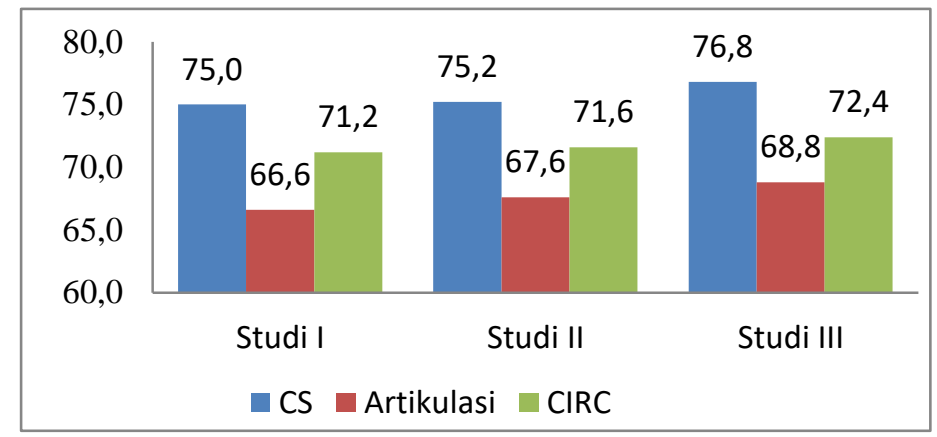

Gambar 1. Perbandingan hasil posttest dari setiap kelas eksperimen

Gambar 1 menunjukkan bahwa skor rerata posttest dalam studi pertemuan kesatu, studi pertemuan kedua, studi pertemuan ketiga di atas menunjukkan ada perbedaan dari setiap treatment yang dilakukan.

\section{Tes Normalitas}

Tes untuk distribusi normal dilakukan pada hasil tes akhir, yaitu posttest hasil pemahaman konsep. Tes normalitas ini dilakbertujuan untuk menentukan suatu data berdistribusi normal atau tidak. Berdasarkan hasil uji normalitas laksanakan berbantuan software SPSS versi 22, dari output dapat disimpulkan bahwa semua data posttest berdistribusi normal dan dapat digunakan sebagai prasyarat untuk analisis data uji t.

\section{Tes Homogenitas}

Uji homogenitas dilakukan dengan Uji Statistik Levine. Adapun output uji homogenitas dapat digambarkan pada Tabel 3 berikut.

Tabel 3. Tes Homogenitas

\begin{tabular}{cccccc}
\hline Study & $\begin{array}{c}\text { Levene } \\
\text { statistic }\end{array}$ & df1 & df2 & Sig. & Ket. \\
\hline $\begin{array}{c}\text { Posttest } \\
\text { Study I }\end{array}$ & 0,038 & 2 & 72 & 0,963 & Homogen \\
$\begin{array}{c}\text { Posttest } \\
\text { Study II }\end{array}$ & 0,836 & 2 & 72 & 0,175 & Homogen \\
$\begin{array}{c}\text { Posttest } \\
\text { Study III }\end{array}$ & 1,787 & 2 & 72 & 0,175 & Homogen \\
\hline
\end{tabular}

Berdasarkan pengujian homogenitas yang telah dilaksanakan pada pertemuan kesatu, pertemuan kedua, dan pertemuan ketiga dihasilkan sig. $>0,05$ hal tersebut dapat dinyatakan homogen.

\section{Analisis Uji Hipotesis}

Uji hipotesis di dalam penelitian dilaksanakan dengan melakukan analisis uji $t$ parametrik yaitu melakukan analisis dua uji sampel independen (independent samples ttest). Hasil uji statistik menggunakan uji $t$ (independent samples t-test) dengan tingkat signifikansi $95 \%$ memperoleh $t_{\text {hitung }}>t_{\text {tabel }}$ dan nilai probabilitas sig. (2-tailed) $0,000<0,05$, dalam pertemuan kesatu, pertemuan kedua dan pertemuan ketiga, ini terlihat adanya 
Fitriyani $^{1}$, Gunawan ${ }^{2} \&$ Lestari $^{3}$ - Efektivitas Pembelajaran Cooperative Script ...

perbedaan keterampilan pemahaman konsep siswa dari perlakuan yang dilakukan di setiap kelas dengan model pembelajaran yang berbeda dan subjek yang berbeda sehingga hipotesis yang diajukan bisa diterima. Penggunaan model pembelajaran didalam proses kegiatan belajar mengajar dapat dilaksakanakan sesuai dengan materi ajar dalam proses pembelajaran. Materi ajar yang disampaikan mempunyai tingkatan kesukaran yang berlainan demikian berarti diperlukan teknik, metode, dan strategi yang bervariasi disesuaikan dengan karakrteristik dari materi ajar tersebut. Penerapan model pembelajaran guna sesuai dengan karakteristik materi ajar tentu dapat berkesesuaian dengan hasil pembelajaran. Tentu saja output belajar yang berhasil merupakan salah satu kontribusi atas penerapan model pembelajaran. Adapun hasil analisis efektivitas model pembelajaran yang diterapkan dalam setiap treatment penelitian yang telah dilakukan menggunakan 3 kelas dalam pembelajaran menujukan bahwa penerapan tiga model pembelajaran dapat menghasilkan kontribusi yang berlainan terhadap kemampuan pemahaman konsep siswa. Pada pertemuan kesatu, pertemuan kedua, dan pertemuan ketiga menunjukkan bahwa penggunaan model pembelajaran CS lebih efektif daripada penggunaan model pembelajaran Artikulasi dan model CIRC. Hasil ini didasarkan dari hasil pengujian nilai rerata yang diperoleh oleh setiap siswa melalui posttest yang sudah diberikan. Berikut Gambar 2 merupkan deskripsi rerata posttest dari setiap treatment yang sudah diberikan.

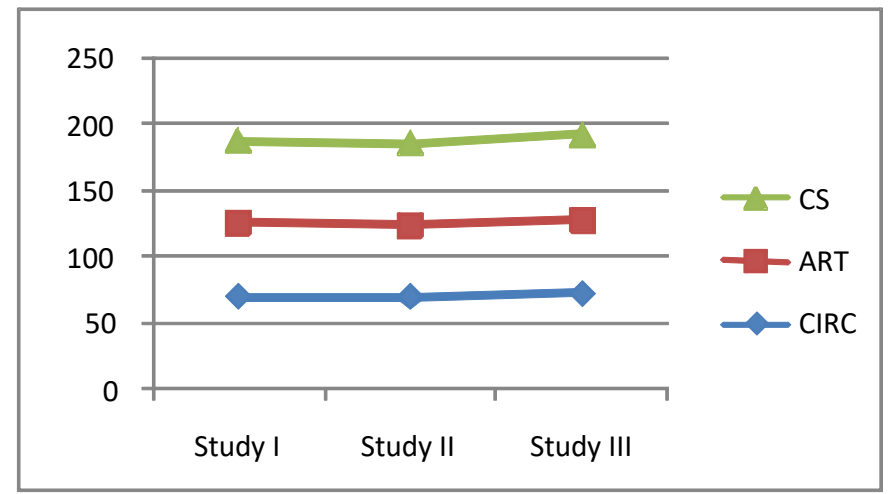

Gambar 2. Nilai Rerata Model Pembelajaran

Gambar 2 menunjukkan bahwa nilai yang didapat dalam penggunaan model pembelajaran CS pada setiap pertemuan skor rerata yang didapat lebih unggul dalam tiap studi dibandingkan dengan penggunaan model Artikulasi dan model CIRC, ini menunjukkan bahwa penggunaan model pembelajaran CS dalam pembelajaran dapat konsisten dalam setiap pertemuan didalam kelas. Berdasarkan hasil analisis menggunakan pendekatan statistik yang relevan dengan penelitian ini, menunjukkan bahwa penggunaan model pembelajaran CS, model pembelajaran Artikulasi dan model pembelajaran CIRC memberikan perbedaan di dalam meningkatkan kemampuan pemahaman konsep siswa.

\section{Efektivitas Model CS dan Model Artikulasi terhadap Pemahaman Konsep Siswa}

Berdasarkan hasil uji statistik berbantuan software SPSS versi 22, adapun temuan penelitian menujukan ada perbedaan signifikan antara kemampuan pemahaman konsep siswa kelas yang menerima penerapan model pembelajaran CS dan kelas siswa yang menerapkan model Artikulasi. Demikian dapat dilihat atas skor rerata dari ketiga model dalam pertemuan kesatu, pertemuan kedua dan pertemuan ketiga yaitu dari ketiga pertemuan yang telah dilakukan dengan menerapkan model pembelajaran CS didapat skor rerata 75,67, kemudian penerapan model Artikulasi didapat skor rereta 67,67 dan penerapan model CIRC didapat skor rerata 71,73 . Dari skor rereta yang didapatkan jelas 
bahwa ada perbedaan dalam hal skor rerata siswa tetapi perbedaannya tidak signifikan. Selanjutnya dapat terlihat apakah ada perbedaan keterampilan pemahaman konsep antara siswa yang diberikan penerapan model CS dan model Artikulasi, maka kedua tes perbedaan tersebut analisis dengan uji rerata sebagai uji t. Uji t dilakukan pada skor yang didapat secara berurutan, yaitu dari pertemuan kesatu, pertemuan kedua dan pertemuan ketiga. Adapun hasil uji beda dua rerata sig. (2-tailed) didapat nilai $0,000<0,05$, berarti ada perbedaan yang signifikan antara siswa yang menerima pembelajaran dengan menerapkan model CS dan siswa yang menerima pelajaran dengan menerapkan model Artikulasi.

Kemudian sesudah mengetahui ada perbedaan yang signifikan dari output skor rerata postest pada pertemuan kesatu, pertemuan kedua dan pertemuan ketiga, ditemukan bahwa siswa yang menerima pembelajaran dengan menerapkan model CS lebih unggul dibandingkan dengan siswa yang menerima pembelajaran dengan menerpkan model Artikulasi. Hal ini berarti penerapan model CS ini dapat memberikan kontribusi untuk meningkatkan kemampuan pemahaman konsep siswa dari penerapan model Artikulasi. Hal ini sejalan dengan hasil penelitian yang dilakukan (Fatmawati, 2016; Hermawati et al., 2020; Rifa'i, 2015; Suwardi \& dkk, 2016) mengindikasikan bahwa model pembelajaran CS berpengaruh signifikan terhadap pemahaman siswa dalam muatan pembelajaran IPS.

\section{Efektivitas model Artikulasi dan model CIRC terhadap Pemahaman Konsep Siswa}

Berdasarkan hasil uji statistik berbantuan software SPSS versi 22, temuan penelitian menunjukkan ada perbedaan signifikan antara kemampuan pemahaman konsep siswa yang menerima pembelajaran menerapkan model Artikulasi dan siswa yang mendapat pembelajaran dengan menerapkan model CIRC. Ini dapat dilihat berdasarkan skor rerata atas penggunaan tiga model dalam pertemuan kesatu, pertemuan kedua dan pertemuan ketiga, yaitu dari tiga pertemuan yang telah dilakukan siswa yang mendapat pembelajaran dengan penggunaan model pembelajaran artikulasi didapat skor rerata 67,67 dan siswa yang mendapat pembelajaran dengan penggunaan model CIRC didapat skor rerata 71,73. Dari skor rerata yang didapat jelas bahwa ada perbedaan dalam hal skor rerata siswa tetapi perbedaannya tidak signifikan. Selanjutnya untuk mengetahui adanya perbedaan dalam keterampilan pemahaman konsep antara siswa yang menerima pembelajaran dengan model artikulasi dan model CIRC, dua tes perbedaan rerata sebagai uji t. Uji $t$ dilakukan pada data yang diperoleh secara berurutan, yaitu dari pertemuan kesatu, pertemuan kedua, dan pertemuan ketiga. Adapun dalam pertemuan kesatu hasil dari dua tes perbedaan rata-rata sig. (2-tailed) nilai 0,029 $<0,05$, yang berarti bahwa ada perbedaan yang signifikan antara siswa yang menerima pembelajaran dengan menggunakan model Artikulasi dan siswa yang menerima pembelajaran dengan menggunakan model CIRC. Pada pertemuan kedua hasil uji beda dua rata-rata sig. (2-tailed) nilai 0,033<0,05, berarti bahwa ada perbedaan yang signifikan antara siswa yang menerima pembelajaran dengan menerapkan model artikulasi dan siswa yang menerima pembelajaran dengan menerapkan model CIRC. Pada pertemuan ketiga hasil uji beda dua rata-rata sig. (2-tailed) nilai $0,023<0,05$, yang berarti bahwa ada perbedaan yang signifikan antara siswa yang menerima pembelajaran dengan menggunakan model artikulasi dan siswa yang menerima pembelajaran dengan menerapkan model CIRC.

Setelah mengetahui adanya perbedaan yang signifikan dan berdasarkan hasil rerata posttest dalam pertemuan kesatu, pertemuan kedua dan pertemuan ketiga ditemukan bahwa siswa yang menerima pembelajaran dengan menggunakan model CIRC lebih unggul dibandingkan dengan siswa yang menerima pembelajaran dengan menggunakan model artikulasi. Artinya penggunaan model pembelajaran CIRC berkontribusi pada peningkatan kemampuan pemahaman konsep siswa dari penggunaan model pembelajaran artikulasi. Hal ini sejalan dengan hasil penelitian yang dilakukan Ariawan et 
Fitriyani $^{1}$, Gunawan ${ }^{2} \&$ Lestari $^{3}$ - Efektivitas Pembelajaran Cooperative Script ...

al., (2018); Dewi et al., (2019); Durukan, (2011); Khoirunisa et al., (2017); Marliana et al., (2019) yang mengindikasikan bahwa model pembelajaran CIRC berkontribusi pada pemahaman konsep siswa sehingga hasil belajar dapat meningkat dalam pembelajaran di sekolah dasar.

\section{Efektivitas Model CS dan Model CIRC terhadap Pemahaman Konsep Siswa}

Berdasarkan hasil uji statistik berbantuan software SPSS versi 22, temuan penelitian menunjukkan ada perbedaan yang signifikan antara kemampuan pemahaman konsep siswa yang menerima pembelajaran menggunakan model CS dan siswa yang menerima pembelajaran menggunakan model CIRC. Hal ini dapat dilihat berdasarkan hasil skor rerata dari ketiga model dalam pertemuan kesatu, pertemuan kedua dan pertemuan ketiga, yaitu dari masing-masing tiga pertemuan yang telah dilakukan skor rerata siswa yang yang menerima pembelajaran menggunakan model CS diperoleh skor rerata 75,67, model Artikulasi diperoleh skor rerata 67,67 dan siswa yang menerima pembelajaran menggunakan model model CIRC diperoleh skor rerata 71,73. Hasil dari skor rerata yang didapat dari ketiga model yang diterapkan jelas bahwa ada perbedaan dalam hal skor rerata siswa tetapi perbedaannya tidak signifikan. Demikian untuk melihat apakah ada perbedaan dalam pemahaman konsep siswa antara siswa yang menerima pembelajaran model CS dengan siswa yang menerima pembelajaran model CIRC, dua tes perbedaan rerata sebagai uji t. Uji t dilakukan pada data yang didapat secara berurutan, yaitu dari pertemuan kesatu, pertemuan kedua, dan pertemuan ketiga. Pada pertemuan kesatu hasil uji beda dua rerata sig. (2-tailed) nilai $0,027<0,05$, berarti bahwa ada perbedaan yang signifikan antara siswa yang menerima pembelajaran dengan menerapkan model CS dan siswa yang menerima pembelajaran dengan menerapkan model CIRC. Dalam pertemuan kedua hasil uji beda dua rata-rata sig. (2-tailed) nilai $0,033<0,05$, yang berarti bahwa ada perbedaan yang signifikan antara siswa yang menerima pembelajaran menerapkan model CS dan model CIRC. Dan dalam pertemuan ketiga hasil uji beda dua rata-rata sig. (2-tailed) nilai $0,020<0,05$, yang berarti ada perbedaan yang signifikan antara siswa yang menerima pembelajaran dengan menerapkan model CS dan model CIRC.

Demikian setelah terlihat adanya daya beda yang signifikan dan berdasarkan hasil skor rerata postest dalam pertemuan kesatu, pertemuan kedua dan pertemuan ketiga, ditemukan bahwa siswa yang menerima pembelajaran dengan menggunakan model CS lebih unggul dibandingkan dengan siswa yang menerima pembelajaran dengan menggunakan model CIRC. Selain itu, hal ini mengindikasikan bahwa penggunaan model CS berkontribusi untuk meningkatkan pemahaman konsep siswa dari model CIRC. Demikian sejalan dengan hasil penelitian (Boleng dan Maasawet, 2019; Rajab dan Puspita, 2018; Salamiah, 2018) yang mengungkapkan bahwa dengan penggunaan model pembelajaran CS dapat mengembangkan strategi pembelajaran dan dapat meningkatkan hasil belajar siswa di sekolah dasar.

\section{SIMPULAN}

Atas penemuan dari hasil penelitian yang dilakukan, model CS berkontribusi lebih efektif dalam menumbuhkan kemampuan pemahaman konsep siswa dibanding dengan model Artikulasi dan model CIRC. Ini berarti bahwa pada saat belajar siswa lebih antusias dalam berpartisipasi dalam kegiatan belajar siswa dapat secara aktif berdiskusi dan mengajukan pertanyaan dalam pembelajaran yang lebih maju di sini menunjukkan kualitas pembelajaran yang menerapkan model pembelajaran CS lebih efektif dapat meningkatkan keterampilan kemampuan pemahaman siswa. Penerapan model CS pada pemahaman konsep menunjukan efektivitas yang sangat signifikan dibanding dengan menerapkan model pembelajaran Artikulasi dan CIRC. Terlihat analisis uji t independent sample didapat skor signifikan sebesar 0,000<0,05. Demikian hal ini didukung pula dengan hasil observasi 
di dalam proses pembelajaran sudah menunjukan siswa lebih aktif dan antusias serta mempunyai rasa ingin tahu yang tinggi, di sini menunjukkan kualitas pembelajaran yang menerapkan model CS lebih efektif untuk meningkatkan pemahaman konsep siswa. Kemudian dari hasil perhitungan 75 siswa diperoleh skor rerata siswa pada pertemuan kesatu sebesar 75,0, pertemuan kedua diperoleh skor rerata sebesar 75,2 dan pertemuan ketiga diperoleh skor rerata sebesar 76,8. Dari hasil perhitungan tersebut peningkatan kelas eksperimen yang menerima pembelajaran dengan menerapkan model CS lebih signifikan dibanding kelas yang menerima pembelajaran dengan menerapkan model artikulasi pada pertemuan kesatu diperoleh skor rerata sebesar 66,6, pertemuan kedua diperoleh skor rerata sebesar 67,6 dan pertemuan ketiga diperoleh skor rerata sebesar 68,8 dan penggunaan model pembelajaran CIRC pada pertemuan kesatu diperoleh skor rerata sebesar 71,2, pertemuan kedua diperoleh skor rerata sebesar 71,6 dan pertemuan ketiga diperoleh skor rerata sebesar 72,4.

Adapun berdasar simpulan di atas, selanjutnya peneliti memberikan saran-saran khususnya pada SDN Pakembangan, SDN Kutakembaran 1 dan SDN Kutakembaran 2 untuk mengupayakan pelatihan bagi guru agar dapat mendukung pelaksanaan pembelajaran, terbiasanya penggunaan pembelajaran inovatif bertujuan tercapainya tujuan pembelajaran yang sesuai dengan harapan.

\section{DAFTAR PUSTAKA}

Abidin, Z. (2020). Efektivitas Pembelajaran Berbasis Masalah, Pembelajaran Berbasis Proyek Literasi, Dan Pembelajaran Inkuiri Dalam Meningkatkan Kemampuan Koneksi Matematis. Profesi Pendidikan Dasar, 7(1), 37-52. https://doi.org/10.23917/ppd.v7i1.10736

Ariawan, V. A. N., Utami, N. T., \& Rahman, R. (2018). Peningkatan Keterampilan Membaca Pemahaman Siswa Sekolah Dasar Melalui Implementasi Model CIRC Berbantuan Media Cetak. Al-Aulad: Journal of Islamic Primary Education, 1(2), 95-104. https://doi.org/10.15575/al-aulad.v1i2.3529

Bintarini, N. K., Marhaeni, A. A. I. N., \& Lasmawan, I. W. (2013). Determinasi Pemanfaatan Lingkungan Sekitar Sekolah Sebagai Sumber Belajar Terhadap Gaya Belajar Dan Pemahaman Konsep IPS Pada Siswa Kelas IV SDN Gugus Yudistira Kecamatan Negara e-Journal Program Pascasarjana Universitas Pendidikan Ganesha. In e-Journal Program Pascasarjana Universitas Pendidikan Ganesha (Vol. 3). (Doctoral dissertation, Ganesha University of Education).

Boleng, D. T., \& Maasawet, E. T. (2019). The integration of PBL and cooperative script to empower critical thinking skills of biology students. Jurnal Pendidikan Biologi Indonesia, 5(2), 217-228. https://doi.org/10.22219/jpbi.v5i2.7952

Christina, L. V., \& Kristin, F. (2016). Efektivitas Model Pembelajaran Tipe Group Investigation (Gi) Dan Cooperative Integrated Reading and Composition (Circ) Dalam Meningkatkan Kreativitas Berpikir Kritis Dan Hasil Belajar Ips Siswa Kelas 4. Scholaria: Jurnal Pendidikan Dan Kebudayaan, 6(3), 217. https://doi.org/10.24246/j.scholaria.2016.v6.i3.p217-230

Dewi, N. R., Pamelasari, S. D., \& Hidayati, W. (2019). The Effectiveness Of Science Uno Card-Assisted CIRC Method On Classification And Scientific Communication Skills. 8(1), 113-122. https://doi.org/10.23887/jpi-undiksha.v8i1.11779

Durukan, E. (2011). Effects of cooperative integrated reading and composition (CIRC) technique on reading-writing skills. Educational Research and Reviews, 6(1), 102109.

Fatmawati, L. (2016). Peningkatan Keaktifan Dan Pemahaman Konsep Ips Melalui Model Learning Cycle 5E. Jurnal Prima Edukasia, 4(2), 148 https://doi.org/10.21831/jpe.v4i2.9488 
Fitriyani $^{1}$, Gunawan ${ }^{2} \&$ Lestari $^{3}$ - Efektivitas Pembelajaran Cooperative Script ...

Fitriyani, Y., \& Supriatna, N. (2019). Effect of Effectiveness of Application Used Cooperative Learning Model Type Numbered Head Together (NHT), Teams Games Tournament (TGT) and Course Review Horay (CRH) against Increased Critical Thinking Skill of Students. The 2nd International Conference on Elementary Education, 2(1), 955-968. http://proceedings.upi.edu/index.php/icee/article/view/707/623

Fraenkel, J. R., Wallen, N. E., \& Hyun, H. H. (2012). How to Design and Evaluate Research in Education (Vol 8). New York: McGraw Hill.

Gillies, R. M. (2003). Structuring cooperative group work in classrooms. International Journal of Educational Research, 39(1-2), 35-49. https://doi.org/10.1016/S08830355(03)00072-7

Hakim, Z. R., Taufik, M., \& Siti Mujiwati. (2019). Penerapan Model Problem Based Learning (Pbl) Terhadap Kemampuan Pemecahan Masalah Pada Mata Pelajaran Ips Peserta Didik Kelas Iv Sekolah Dasar. 4(1), 60-65.

Hermawati, E., Sari, M. Z., \& Fitriyani, Y. (2020). The effectiveness of using cooperative learning models toward pre-service elementary teacher's understanding on social science education course: a comparison for cooperative script, articulation, and guided note taking. Indonesian Journal of Elementary Teachers Education (IJETE), 1(1), 39-48.

Huda, M. (2019). Model-model pengajaran dan pembelajaran. Yogyakarta: Pustaka Pelajar.

Indriani, D. E. (2017). Cooperative Scripts Model in Civic Education for Elementary School Students. Humaniora, 8(2), 105. https://doi.org/10.21512/humaniora.v8i2.3888

Khoirunisa, E., Gunarhadi, Choiri, A. S., \& Sunardi. (2017). The Use Of Cooperative Integrated Reading And Composition (CIRC) Method To Improve Reading Comprehension Ability Of Visually Impaired Students In The 3 Rd Grade Of SD SLB A Ykab Surakarta , Indonesia. European Journal of Special Education Research, 2(1), 59-70. https://doi.org/10.5281/zenodo.224515

Maftuh, B. (2013). Body of Knowledge Pendidikan IPS: Makalah yang disampaikan pada Seminar Nasional di Universitas Kanjuruhan.

Maksum, A., \& Sedyawanti, sri martini rahayu. (2013). Model Cooperative Script Berpendekatan Science, invironment, Technologi, And Society (SET). Jurnal Inovasi Pendidikan Kimia, 7(1), 1072-1082.

Marliana, N., Wawan, D., \& Kuswari, U. (2019). Cooperative Integratif Reading And Composition ( CIRC ) Method To Increase Students' Reading For Comprehension Ability ( Experimental study on students of Class XI IPA SMA Negeri 1 Anyer Academic Year 2018/2019). UI Proceeding on Social Science and Humanties, 3, 97106.

O’Donnell, A. M., \& Dansereau, D. F. (2000). Interactive effects of prior knowledge and material format on cooperative teaching. Journal of Experimental Education, 68(2), 101-118. https://doi.org/10.1080/00220970009598497

Prasetyo, Z. K. (2014). Pembelajaran dan kompetensi pendidikan abad 21. Bunga Rampai Kajian Pendidikan Karakter, Literasi, dan Kompetensi Pendidik dalam Menghadapi Abad 21. Universitas Negeri Yogyakarta.

Rahmad. (2016). Kedudukan Ilmu Pengetahuan Sosial ( IPS ) pada Sekolah Dasar. Muallimuna: Jurnal Madrasah Ibtidaiyah, 2(1), 67-68. http://ojs.uniskabjm.ac.id/index.php/muallimuna

Rahman. (2019). Model Mengajar dan Bahan Pembelajaran. Sumedang-Jatinangor: Alqaprint.

Rajab, A. P., \& Puspita, L. (2018). Pengaruh Model Cooperative Script Terhadap Kemampuan Membaca Pemahaman Siswa Kelas V SD Negeri 137 Palembang. Jurnal Inovasi Sekolah Dasar, 5(1), 16-23.

Rifa'i, R. (2015). Penggunaan Model Cooperative Script Terhadap Kemampuan 
Pemahaman Dan Komunikasi Matematis Siswa. Jurnal Kajian Pendidikan Dan Pengajaran, 1(1), 30.

Rosidah, A. (2016). Penerapan Media Pembelajaran Visual Untuk Meningkatkan Pemahaman Konsep Siswa Pada Mata Pelajaran IPS. Cakrawala Pendas, 2(2), $121-$ 126.

Salamiah. (2018). Penerapan Model Pembelajaran Cooperative Tipe Script Untuk meningkatkan Hasil Belajar Siswa. Jurnal PAJAR Pendidikan Dan Pengajaran, 1(1). https://doi.org/10.1017/СBO9781107415324.004

Slavin, E., R. (2008). Cooperative Learning-Teori, Riset Dan Praktik. Nusa Media.

Sundari, K., \& Andriana, S. (2018). Upaya Meningkatkaan Pemahaman Konsep Siswa Melalui Model Artikulasi Pada Mata Pelajaran IPS di Kelas V SDIT An-Nadwah Bekasi. Pedagogik, VI(2), 109-116.

Suprijono. (2018). Cooperative Learning Teori dan Aplikasi Paikem. Pustaka Pelajar.

Suwardi, Y. P., \& dkk. (2016). Pengaruh cooperative script terhadap kemampuan berpikir kritis dan hasil belajar siswa kelas $x$ sma negeri 7 malang. 1-14.

Syafrudin, U., Darmawan, D., \& Ridwan, I. R. (2019). Penerapan Model Cooperative Script dalam Pembelajaran PKn untuk Meningkatkan Hasil Belajar Siswa Pada Konsep Bangga Sebagai Anak Indonesia. AR-RIAYAH: Jurnal Pendidikan Dasar, 2(2), 147. https://doi.org/10.29240/jpd.v2i2.661

Uno, H. B., \& Umar, M. K. (2009). Mengelola Kecerdasan dalam Pembelajaran. Bumi Aksara. 